\title{
Institutional mission statements: discursive construction of organizational identity in Canadian post-secondary education
}

Sebin Jung ${ }^{1}$

\begin{abstract}
To navigate websites of educational institutions when choosing where to study, future students need to have high levels of literacy to understand how such organizations represent themselves to the world. This study examines the discursive construction of organizational identity in the mission statements of selected Canadian post-secondary institutions by applying English for Specific Purposes rhetorical move/step genre analysis and lexico-grammatical analysis to understand the rhetorical organization of the mission statements and vocabulary and grammatical patterns that characterize each individual move. The findings of the analyses of a small corpus of 14 mission statements show that all mission statement samples include 'commitments' as the obligatory move; however, the primary commitments of the university mission statements differ from those of colleges, thus reflecting differences in institutional purposes and functions of the two types of post-secondary educational institutions. Practical and pedagogical implications of the study are discussed.
\end{abstract}

Keywords: Organizational identity; Mission statements; Genre analysis; Move/step analysis.

\section{Declarações de missão institucional: construção discursiva da identidade organizacional na educação pós-} secundária Canadense

\section{Resumo}

Para navegar nas páginas de instituições educacionais quando escolhendo onde estudar, futuros alunos precisam ter altos níveis de letramento para entender como tais organizações se representam para o mundo. Este estudo examina a construção discursiva da identidade organizacional nas declarações de missão de instituições Canadenses pós-secundária selecionadas por meio da aplicação do procedimento de análise de gêneros (SWALES, 1990) o Inglês para Fins Específicos de movimentos e passos e análise léxico-gramatical (HYON, 2018) para entender a organização retórica das declarações de missão e padrões gramaticais e lexicais que caracterizam cada movimento individual. Os resultados das análises de um pequeno corpus de 14 declarações de missões mostram que todas as amostras de declaração de missão incluem 'comprometimentos' como o movimento obrigatório; entretanto, os comprometimentos primários das declarações de missão da universidade diferenciam-se daqueles de faculdades, portanto refletindo diferenças em propósitos institucionais e funções de dois tipos de instituições educacionais póssecundária. Implicações práticas e pedagógicas do estudo são discutidos.

Keywords: Identidade Organizacional; Declaração de missão; Análise de Gênero; Análise de movimentos.

\section{Introduction}

Nowadays, academic literacy is no longer confined to the limits of the classroom. To navigate complex systems of educational institutions when choosing a university or a college,

\footnotetext{
${ }^{1}$ Carleton University, Ottawa, sebinjung@cmail.carleton.ca
} 
future students need to be aware of the ways such organizations represent themselves to the world. Genre analysis may serve a tool that fosters such literacy.

Institutional websites contain multiple texts, which are aimed at prospective students and other audiences. One of such texts that almost always is included in a post-secondary institutions' websites is mission statement. Mission statement is a document that provides information about an organization: what it is and what it does (FALSEY, 1989). Since mission statements have been widely adopted as a strategic management and communication tool by different organizations (DAVID, M. E.; DAVID, F. R.; DAVID, F. R, 2014), numerous studies have been conducted on mission statements. In particular, organizational identity, defined as a sum of central, enduring, distinctive features of an organization (ALBERT; WHETTEN, 1985), has been an important focus of research in the business world as it has been viewed as a core component of an organization's mission (GIOIA; PATVARDHAN; HAMILTON; CORLEY, 2013).

Previous research that investigated characteristics of post-secondary education institutions indicates that college and university purposes, sizes, reputation, and total enrollment differ significantly (LABIANCA; FAIRBANK; THOMAS; GIOIA; UMPHRESS, 2001). And yet, so far, there has been only limited research, which has examined organizational identity in mission statements of colleges and universities (ALLISON, 2017). There is even less research that focuses on Canadian post-secondary institutions' mission statements. This study intends to fill the gap in the existing literature by examining how organizational identity is represented and communicated in the mission statements of Canadian colleges and universities by investigating their rhetorical organization (SWALES, 1990) and lexico-grammatical features (HYON, 2018) and by proposing pedagogical implications of this type of research.

The paper is organized in five sections. The theoretical background section introduces important concepts such as 'genre', 'communicative purpose' and 'discourse community' and provides an overview of the English for Specific Purposes (ESP) genre approach (SWALES, 1990). The literature review section provides a review of previous literature and discusses the posed research questions. Then, the methods section describes the data, methods of data collection, and data analysis procedures. The findings and discussion section presents the outcomes of the analysis and discusses their meaning and significance. Lastly, the conclusion section summarizes the findings of the study and discusses the implications of this research. 


\section{Theoretical Background}

This section explains important concepts in ESP genre-based studies including 'genre', 'communicative purpose' and 'discourse community', and discusses communicative purpose in connection with genre and rhetorical structure.

Since 1980s, it has been widely agreed that genres are best conceptualized as "goaldirected or purposive" types of texts, and the goal or purpose has been used as the primary criterion for determining a generic type or category of text (ASKEHAVE; SWALES, 2001, p.195). One of the well-known approaches to genre studies was proposed by Swales (1990) within the ESP field. According to Swales (1990), genre is "a class of communicative events" (p.58) with some shared set of communicative purposes, or communicative goals, which can be achieved through the use of language. These purposes, recognized by members of a community (referred to as a discourse community), in which the genre occurs, are believed to provide the rationale for the genre and shape its rhetorical structure. However, such communicative purposes may be difficult to identify (SWALES, 1990). Askehave and Swales (2001) observed that uncertainties surrounding communicative purpose undermined its claimed role as a means of assigning genre membership. They suggested that it would be prudent to abandon communicative purpose as an immediate or even a quick method for sorting texts into generic categories. However, they proposed that genre analysts can and should retain the concept of communicative purpose as a valuable and long-term outcome of the analysis.

'Discourse community' is an important notion closely associated with Swales's interpretation of genre. Swales (1990) proposed six defining characteristics for identifying a group of individuals as a discourse community: a set of common public goals, mechanisms of intercommunication, feedback and information through a participatory mechanism, presence of one or more genres to further the community's aims, specific shared lexis, and inclusion of both 'apprentices' and 'experts' with a suitable degree of relevant expertise (pp.24-27). In this way, the concept of 'discourse community' is differentiated from the concept of the 'speech community' such as voters for a political party and faculty of a university, which is defined by shared speech.

In the ESP approach, texts within a genre are seen as employing particular rhetorical 
'moves', defined as functional units designed to achieve the communicative purposes of a text, and 'steps', defined as sub-parts of the move (SWALES, 1990). The moves are further identified depending on their frequency of occurrence:

Some of the moves in a genre are obligatory, in that they are necessary to achieve the communicative purpose of the genre, whereas others are optionalthose which speakers or writers may choose to employ if they decide those moves add to the effectiveness of the communication but do not alter the purpose of the text (see Hasan, 1989). Each of these moves has its own purpose and contributes to the realization of the overall communicative purpose of the genre (HENRY; ROSEBERRY, 1998, p. 147).

The ESP approach to genre analysis is realized through the determination of a preliminary communicative purpose, examination of the genre's rhetorical move/step organization including identification of obligatory and optional moves, investigation of the textual and linguistic features of each move, and re-purposing of the genre (ASKEHAVE; SWALES, 2001) (BARWASH; REIFF, 2010). As this study examines how organizational identity is projected in college and university mission statements and how to apply this method in a classroom, it adopts the ESP approach to genre analysis as its theoretical and analytical framework.

\section{Literature Review}

This section introduces the mission statement as a genre and the concept of organizational identity in relation to organizational mission, providing a review of previous literature in corporate and institutional mission statements. Drawing on previous studies which suggest the differences in mission statements used by different types of educational institutions, this study investigates the construction of college and university mission statements as well as their representation of organizational identity.

The mission statement, also referred to as the statement of purpose, values, goals and strategies, creed and philosophy, is a document that provides information about the organization's commitments, goals, values, beliefs, its unique features or nature (PEARCE; DAVID, 1987). Sharing such similar purposes and functions (HYON, 2018), mission statements are recognized as a type or category of a written text, thus constituting an "organizational genre" 
(SWALES; ROGERS, 1995). Though this particular genre is reported to be varied in the way it is composed and used by organizations, previous studies on content of corporate mission statements confirmed a considerable overlap in their content (MORPHES; HARTLEY, 2006). For instance, Pearce II and David (1987) identified 'customers', 'product and services', 'commitment for growth', 'philosophy', 'self-concept' and 'desired public image' as recurrent key components of mission statements. These components reflect what the organization stands for, what it believes to be, and how it is distinguishable from other organizations.

The organizational identity is the concept that is defined as a sum of central, distinctive, and durable features of an organization (ALBERT; WHETTEN, 1985). While organizational identity is something that is perceived by the members of the organization, it is clearly influenced by outsiders in that it is continuously negotiated by the members of the organization via their interactions with external stakeholders (GIOIA; PRICE; HAMILTON; THOMAS, 2010). Centrality means that organizational identity is not randomly formed or arbitrarily affected by external events but includes features that are important and essential to the organization. Distinctiveness is related to the uniqueness of an organization and usually includes organizational ideology, philosophy, and culture, which help the organization differentiate itself from others. Lastly, durability emphasizes the enduring nature of the organizational identity, which implies that organizational change may be difficult due to the impact that the loss of the organizational identity may bring to the organization (ALBERT; WHETTEN, 1985). The core and stable characteristics of the organization, or, in other words, its centrality and durability, and unique and changeable characteristics of the organization, such as its distinctiveness, form an organizational identity together and constitute a key component of the organizational mission (GIOIA et al., 2013).

Such a close relationship between the organizational identity and organizational mission has prompted numerous studies in the business world. For example, Swales and Rogers (1995) and Leuthesser and Kohli (1997) explored how corporations used language to project their identity through mission statements. Williams (2008) studied strategies employed by corporations to create corporate identity and explored the link between the mission statement content and organizational performance. Sun and Jiang (2013) studied differences in corporate ideologies and identities in Chinese and U.S companies based on the differences in the language 
of their mission statements.

However, in the world of education, despite a widespread use of mission statements, limited research has been conducted on the organizational identities presented in college or university mission statements. In fact, Hladchenko (2016) conducted seemingly the only study that explicitly mentioned organizational identity in relation to academic mission statements. The researcher examined the most popular commitments and goals in 46 mission statements of Ukrainian universities to compare the changes before and after the adoption of a new legislation on higher education in 2014, which led the transition from the Soviet to European education model. While this study found common primary commitments in the interpretation of institutional demands, it focused more on the impact of social change on the content of the mission statements than on the organizational identity. The study by Atai and Asadnia (2017), which did not directly focus on the organizational identity, confirmed that it is is an important element of the mission statement genre. By analyzing the organization of 500 mission statements of the world's top-ranked universities, the researchers found that the mission statement genre is realized through five moves, namely 'commitments, goals and orientations', 'source of reputation', 'services and supports', 'current status of development' and 'global state', among which, 'commitments, goals and orientations' is the only obligatory move, present in all mission statement samples. The study also reported 'identity' as one of the frequent steps found in the 'current status of development' move.

Other studies suggested the differences in mission statements used by different types of institutions. Morrish and Saunton (2013) found significant differences in content between research universities and business schools, which were attributed to the different purposes of the universities studied. Morphew and Hartley (2006) explored the elements of U.S postsecondary institutions' mission statements to investigate differences in content across institutional types. Based on thematic analysis of 300 mission statements, the study found discernable patterns of the elements in mission statements across institutional levels (baccalaureate, master's, and doctoral/research) and control (public vs. private), which claimed to reflect distinctive values of the different institutions. 


\section{Research Questions}

Considering the findings of Morphew and Hartley's (2006) study and given a significant cultural and institutional diversity in purpose, size, reputation and enrollment in college and university mission statements (LABIANCA et al., 2001), this study investigates the extent to which these two types of post-secondary institutions differ in the ways they construct mission statements and discursively construct organizational identity. Accordingly, this paper raises the following questions:

- How is organizational identity discursively constructed in mission statements of Canadian post-secondary institutions?

- Are there any significant differences in the way organizational identity is discursively constructed in mission statements of Canadian colleges and universities? If so, how are their mission statements and projection of the organizational identity different? What are the pedagogical implications of the findings?

\section{Methods}

Mission statements have been collected from public websites of Canadian post-secondary institutions (Appendix A).

\section{Corpus}

The corpus in this study comprised 14 mission statements, including seven (7) university mission statements and seven (7) college mission statements (Appendix A). The texts in the corpus were randomly selected from among public university and college websites to avoid a possible impact of the institutional control (public vs. private). As mission statements generally consist of three meta-components--(1) vision and statement of goals, (2) statement of mission and self-definition, and (3) organization's philosophy and values (BART; BAETZ, 1998)--the corpus texts included all the available components as part of the analysis. The length of the texts in the corpus varied within 60-320 words, as some texts included all the three components mentioned above while some did not. 


\section{Analytical procedure}

The analytical procedure was divided into two major phases: macro-level analysis and micro-level analysis. At the macro-level, a rhetorical move/step analysis was conducted (SWALES, 1990). The reason for such analysis was to understand the generic rhetorical organization of the genre, including the types, frequency, and sequence of the moves and steps presented in the corpus of the mission statements. At the micro-level, a lexico-grammatical analysis was employed to examine vocabulary and grammatical patterns that characterized each identified move.

After having collected the corpus texts, the researcher identified a preliminary communicative purpose of the mission statements based on the initial sense of the texts (cf. ASKEHAVE; SWALES, 2001). Then, moves were marked and labelled informally, according to their sub-purposes. Then, within each move, steps were marked and labelled informally following the same procedure. Through this procedure, the researcher identified which moves were obligatory (i.e., occurring in about $100 \%$ of all texts) and which ones were more optional (occurring in fewer than $100 \%$ of the texts) (HENRY; ROSEBERRY, 1998). After all moves/steps have been identified and categorized, the frequency of moves/steps was examined. Based on the data, similarities and differences in the moves/steps and move frequency patterns in college and university mission statements were compared and contrasted.

Afterwards, through the lexico-grammatical analysis, the researcher examined the vocabulary and grammatical patterns used in each move. All verb phrases were identified and their tense and types were analyzed, as well as content words and expressions used to realize each step were noted. The researcher also examined the grammatical structures used in each move and identified some of the recurring patterns. To add more value and clarity to the analysis, word frequency analysis was conducted using the Antconc 3.5.8 software (ANTHONY, 2019). When using the corpus tool, the researcher excluded the grammatical function words such as pronouns, articles, prepositions and conjunctions and manually extracted 25 most frequent content words from the frequency list. Based on the data, similarities and differences in lexicogrammatical features in college and university mission statements were found. 


\section{HSE}

\section{Study limitations}

Despite the useful findings and practical implications of this study, there are several limitations. First, as the study examined only a limited numbers of mission statements, which represent only a small slice of the overall landscape of colleges and universities in Canada. To increase the trustworthiness of the findings, future research needs to investigate a larger corpus of post-secondary institutions' mission statements.

\section{Discussion of Findings}

\section{Rhetorical structure}

As Table 1 illustrates, the rhetorical move/step analysis indicates that the mission statements in the corpus consist of five moves (M), namely M1 'commitments', M2 'values/principles, M3 'justification of reputation', M4 'current statement of development' and M5 'overview' (Appendix B). The 'commitments' move presents the commitments that the institutions seek to fulfill and the approaches they use to achieve their missions. The 'values/principles' move is associated with the guided values and principles that the institutions hold. The 'justification of reputation' move describes sources of reputation. The 'current statement of development' move expresses 'identity', 'location', 'demography', 'programs offer', 'partnership' and so on. The 'overview' move provides an overview of the 'strategic plan' and 'vision, mission and values' of the institutions. However, out of the five moves, only the 'commitments' move has been identified as obligatory (i.e., present in all mission statement samples). The 'values/principles' move frequently appears in most samples, serving as an obligatory move in college mission statements. The 'current status of development' move is the third frequent move in the corpus. The 'justification of reputation' is only found in one university sample, whereas the 'overview' move is found in two college samples. 


\section{HSE}

Table 1. Functional moves of mission statements of seven Canadian colleges and seven universities

\begin{tabular}{llll} 
Moves & University & College & Total \\
\hline Commitments (M1) & $7=50 \%$ & $7=50 \%$ & $14=100 \%$ \\
Values/principles (M2) & $5=35.7 \%$ & $7=50 \%$ & $12=85.7 \%$ \\
Current status of development (M3) & $2=14.3 \%$ & $3=21.4 \%$ & $5=35.7 \%$ \\
Justification of reputation (M4) & $1=7.1 \%$ & 0 & $1=7.1 \%$ \\
Overview (M5) & 0 & $2=14.3 \%$ & $2=14.3 \%$
\end{tabular}

Source: the author

As follows from TABLE 1, the university mission statements consist of one to three moves, with 'commitments' as the only obligatory move. With regards to the move sequence (see TABLE 2), six out of seven mission statements started with 'commitments' move, and the move sequence 'commitments'- 'values/principles' is the most frequent found in the corpus.

Table 2. The move sequence in mission statements

\begin{tabular}{lll} 
& Move sequence & \% of occurrence \\
\hline Universities (7 texts) & M1-M2 & 57.1 \\
& M1 & 14.3 \\
M1-M3-M1-M2 & 14.3 \\
Colleges (7texts) & M3-M4-M1 & 14.3 \\
& M1-M2 & 28.6 \\
& M1-M2-M3 & 14.3 \\
& M3-M1-M2 & 14.3 \\
& M3-M1-M3-M2 & 14.3 \\
& M5-M1-M2 & 28.6
\end{tabular}

Source: the author

The move structure of one of the university's mission statement differs from those of other universities: it is the only one that begins with the 'current status of development' move and ends with the 'commitments' move (M3-M4-M1). Also, it is the only sample which includes the 'justification of reputation' move.

Compared to the mission statements of universities, the types and sequence of moves in the college mission statements are more diverse. With 'commitments' and 'values/principles' as the obligatory moves, five out of seven college mission statements consist of three or more moves. In terms of the move sequence, three mission statements start with 'commitments' move, two start with the 'overview' move and two, with 'current status of development.' 
While the 'commitments' move is obligatory in both university and college mission statements, steps within the move (FIGURE 1) differ among the samples. In the university mission statements, the most frequently presented steps in the move are 'international perspective' and 'academic excellence.' In the case of the college mission statements, 'practical orientation of education' is the most frequently found step. Such findings help to identify the stable core identity of each type of institution. Also, the variance in the primary commitments between the universities and colleges indicate different institutional purposes and functions that the two types of institutions have.

Figure 1. Steps identified within the 'commitments' move

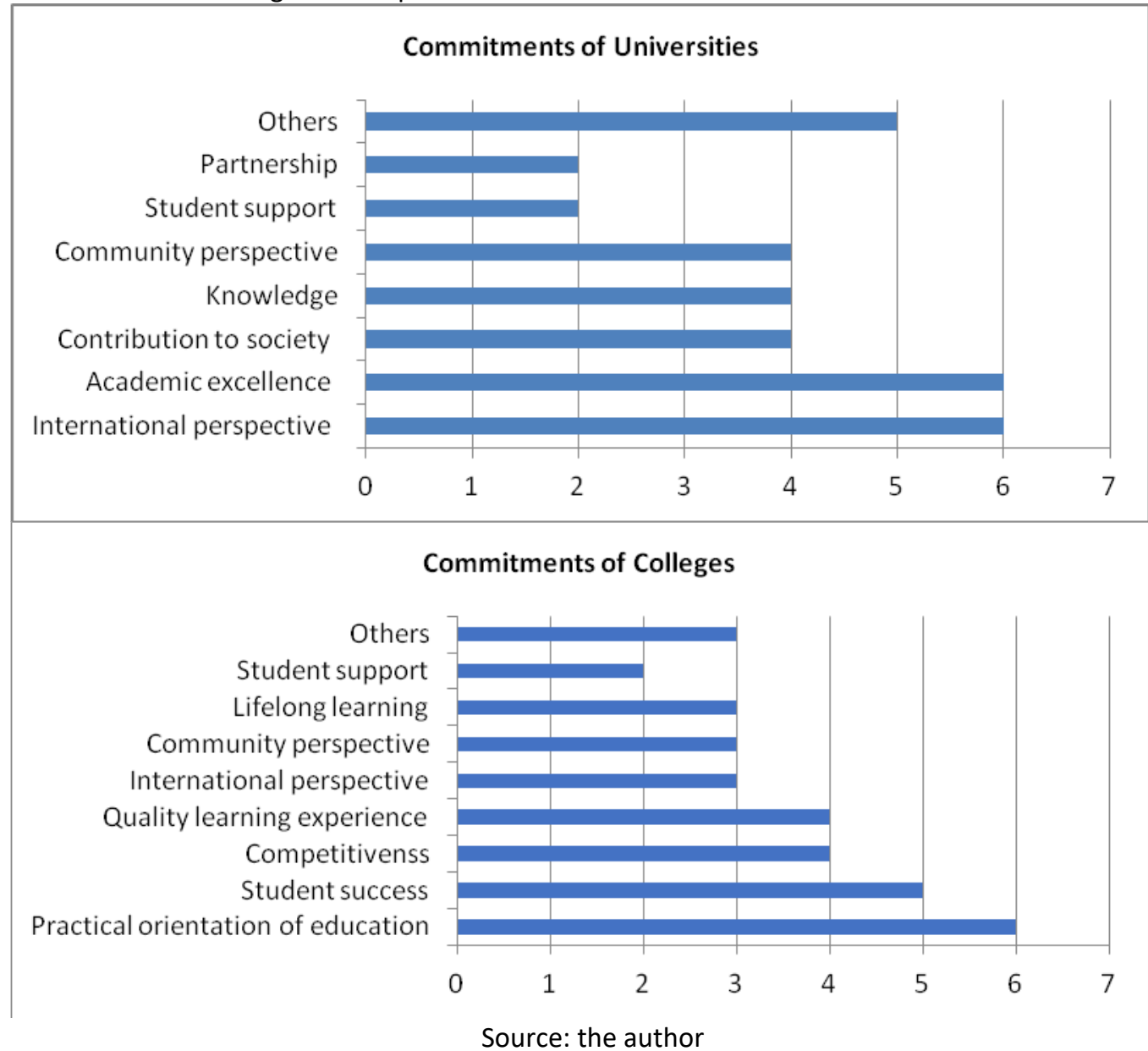

'International perspective' is the most commonly found step in the samples. Yet, it is more prominent in the university mission statements compared to those of colleges as it appears in six out of seven university samples (see highlighted text in the example below): 
(1) We will contribute to a sustainable future by being among the best in the world in areas of special and emerging strengths, through outstanding research, scholarly, and artistic work that addresses the needs and aspirations of our region and the world, and through exceptional teaching and engagement. (University of Saskatchewan)

(2) Enhance and extend our services and capabilities to support the University's goals in Canada and internationally. (University of Waterloo)

(3) York University is open to the world: we explore global concerns. (York University) (4) The University of Alberta gives a national and international voice to innovation in our province, taking a lead role in placing Canada at the global forefront.(University of Alberta)

Considering the results of the study by Knight (1995), which reported that $72 \%$ of universities in her sample included 'internationalism' in their mission statements, it seems that this type of commitment has emerged in the last few decades as more and more universities attempt to draw attention of the international community by establishing their missions in accordance with the prospects of this community (MORPHES; HARTLEY, 2006). This implies that 'international perspective' is a relatively recent component of the identity formed by universities in the last few decades. This component has also started to appear in college mission statements.

While 'academic excellence' and 'knowledge' are the most prominent commitments in the university mission statements, other commitments such as 'contribution to the society', 'community perspective' and 'partnership' express the roles that the universities take on as part of society (highlighted text in the examples below):

(5) The mission of McGill University is the advancement of learning and the creation and dissemination of knowledge, by offering the best possible education, by carrying out research and scholarly activities judged to be excellent by the highest international standards, and by providing service to society. (McGill University)

(6) Sharpen focus on research and scholarship; Enrich the quality and breadth of learning; Fully integrate the university with the community. (University of Calgary)

(7) To create, preserve, communicate and apply knowledge, contributing to the cultural, social and economic well-being of the people of Manitoba, Canada and the world. (University of Manitoba) 
These commitments reflect the roles of universities, which are not limited to education and research but also include knowledge transfer from the academic environment to society as a whole and establish partnerships with other educational institutions and the professional community (MONTESINOS; CAROT; MARTINEZ; MORA, 2008).

Also, the steps within the 'commitments' move in the college mission statements indicate educational direction as well as the role that colleges take on in the community. While the college mission statement samples include commitments such as 'quality learning experience' and 'lifelong learning', their primary commitments are to help their students to achieve 'personal and career success' and meet the needs of the employers through 'practical education' (highlighted text in the examples below):

(8) As leaders in the economic, cultural and intellectual growth of our communities we work collaboratively with all our partners to anticipate and meet education and labour market needs. (Okanagan College)

(9) Provide pathways to success, an exceptional learning experience and a global outlook to meet student and employer needs. (Fanshawe College)

(10) Loyalist College empowers students, faculty, staff, and partners through experiential, economic, cluster-based applied programs and research that provide careerready graduates for, and knowledge transfer to, industry and the community. (Loyalist College)

(11) We will build a seamless bridge between learners and employment as we develop dynamic programs, and workplace-ready graduates who will be the candidates of choice for employers. (George Brown College)

In that sense, one university mission statement (Appendix C) is different from other university samples as it includes 'practical orientation of education' as its primary component, which is more typically found in college mission statements.

Overall, the rhetorical move/step analysis revealed 'commitments' and 'values/principles' are the core elements of the Canadian post-secondary institution mission statement genre as the majority of mission statement samples consisted of 'commitments' and 'values/principles' moves. This finding demonstrates that the main communicative purpose of such institutional mission statement genre is to showcase their commitments and values/principles to the 
stakeholders. Yet, a comparative analysis of the rhetorical moves/steps in the university and college mission statements demonstrates that the university mission statements are generally more uniformly structured whereas college mission statements are more diversely constructed with more moves and differing move sequences. In particular, a detailed analysis of the steps within the 'commitments' move demonstrates that the primary commitments of the university mission statements are different from those of colleges.

\section{Lexico-grammatical features}

The lexico-grammatical analysis of each move shows certain lexical and grammatical features used to realize a specific rhetorical function. Also, the lexical analysis has helped identify how the identity of each institution is discursively constructed in their mission statements. As the analysis has been conducted within each move, this section is divided into five sub-sections.

\section{The 'commitments' move}

An in-depth analysis of the 'commitments' move demonstrates certain grammatical features used to realize its rhetoric function. In terms of sentence type, declarative sentences are most frequently used in mission statements of both types of the institutions while imperative sentences and incomplete sentences starting with 'to + verb' and 'verb + ing' are used much less frequently. As far as the verb tense is concerned, the present tense is dominantly used in most mission statements whereas future tense verbs are used only in one university mission statement and two college mission statements to describe their vision and path. With regards to the grammatical structures, university mission statements are more uniformly structured in expressing their commitments compared to those of colleges, using structures such as 'mission/vision + is $+\mathrm{N} 1+(\mathrm{N} 2+\mathrm{N} 3)^{\prime}, \mathrm{C}^{\prime} \mathrm{V}+\ldots$...(in order) to $+\mathrm{V}^{\prime},{ }^{\prime} \mathrm{V}+\ldots+$ through $+\mathrm{N}$ ' and ' $\mathrm{V}+\ldots \mathrm{by}+$ $\mathrm{V}$ ing', where $\mathrm{N}$ stands for noun and $\mathrm{V}$ for verb. While some of these features are also found in college mission statements, in these statements they much more diversely constructed, and no additional recurring grammatical structures have been identified except 'mission/vision + is + to $+\mathrm{V}$. 
Looking at the lexical choices within the move, different sets of verbs have been attributed to different steps (Appendix D). For instance, verbs such as 'support', 'assist', 'inspire', 'enable' and 'challenge' are used to express institutions' commitments to 'students.' Verbs such as 'cultivate', 'create', 'preserve', 'communicate', 'apply', 'discover' and 'disseminate' are associated with 'knowledge.' Verbs such as 'foster', 'enhance', 'extend', 'promote', 'move closer', 'facilitate' and 'enrich' are used to show the institution's commitment to improve its services and supports, processes, and practices. The verb phrases 'contribute to', partner with', 'integrate with', 'collaborate with' and 'work collaboratively with' are used to describe partnership with industry and community while 'be', 'position as', 'take place', 'build' and 'take a lead role' are used to describe the position of the institution projected into the future. No significant differences have been found in types of verb phrases used by colleges and universities.

Analyzing other content words in the 'commitments' move has also helped to identify some recurring vocabulary within the move. In the 'international perspective' step, words such as 'world', 'global' and 'international' are used repeatedly. In the 'academic excellence' step, words such as 'research' and 'scholarship' are used with adjectives 'outstanding' and 'excellent.' In the 'knowledge' step, the nominalized form of the verbs mentioned in the above paragraph, such as 'creation', 'preservation' and 'dissemination' are used. In the 'contribution to the society' step, words such as 'society', 'our region' and 'public' are frequently used. In the 'practical orientation of education' step, words such as 'work', workplace', 'workforce' 'labor market', 'employer' and 'career' are frequently used. While such recurring lexical choices used in steps make a mission statement less distinguishable from others, using the names of the specific community such as 'Indigenous peoples and communities', 'the community of Calgary' and 'the people of Manitoba' in the 'community perspective' step add more specificity to the missions.

Another finding from the analysis of the 'commitments' move indicates that there is a pattern of stating local and community perspective first and later shifting to the international perspective. For example, the mission statements of two Canadian universities refer to 'people of Manitoba [a Canadian province], Canada and the world' and the 'opportunities in Canada and internationally.' Mission statements of two colleges also show a similar pattern. 


\section{The 'values/principles' move}

An analysis of the 'values/principles' move has also shown certain lexico-grammatical features, which realize its specific rhetorical function. With regards to the generic structure of this move, a significant difference in mission statements of the two types of institutions has been found. In university mission statements, this move was very brief and concise, and consisted of a list of nouns in one sentence without further explanation of each value or principle. Most college mission statements, however, are longer as they provide detailed explanations of each value. This difference affects the types of verb phrases used within the move by the two types of institutions. For instance, in university mission statements, a relatively limited range of verb phrases such as 'are committed to', 'make', 'embrace', 'articulate', 'achieve', 'value', 'rely on' and 'reflect' are used. In college mission statements, a wider range of verb phrases such as 'respect', 'celebrate', 'act with', 'expect', 'listen', 'work', 'achieve', 'focus', 'involve', 'utilize', 'embrace', 'engage', 'create', 'acknowledge', 'are responsible for', 'guide', 'attend to', 'focus', 'provide', 'design', 'build', 'use', 'eliminate', 'guide', 'foster', 'commit', 'hold' and 'show' are found. In terms of the sentence type, declarative sentences are predominantly used while imperative sentences are used in one college mission statement only. As for the verb tense, most statements are written in the present tense with only one of them written in the future tense.

In addition, analyzing other content words within the 'values/principles' move helps to understand how the institutional values/principles are expressed in university and college mission statements. While similar value/principles are presented in mission statements of both types of the institutions, some differences persist. In the university mission statements in the corpus, 'academic freedom' seems the most prioritized value, followed by other academicrelated values such as 'excellence' and 'creativity/innovation', and moral values such as 'integrity', 'equity', and 'inclusiveness/inclusion/inclusivity.' Such a finding is similar to the findings from the 'commitments' move, which also prioritized academic-related commitments such as 'academic excellence' and 'knowledge.' In the college mission statement samples, however, moral and attitudinal values such as 'respect/caring', 'engaging/ relationship/learning community', 'accountability', 'ethical behavior/transparency/ integrity' and 'diversity/openness' have a more visible presence than academic values such as 'learning' and 'excellence.' Besides, 
'student success/focus' is another important value that dominates college mission statements and is practically absent from the university mission statements.

While the majority of the university samples include similar types of values and structures in the move, two university mission statements are distinguishable from others by a) presenting a brief description of the historical origins of the institution to highlight that its values are not arbitrarily formed but "deeply held" (this is the only mission statement that claims "history and traditions' as its institutional value); b) including an institutional slogan in its mission statement at the very end of the move.

\section{The 'current status of development' move}

An analysis of this move has also shown certain lexico-grammatical features that realize its specific rhetorical function. This move is typically expressed through declarative sentences, mostly in the present tense. In terms of the types of verb phrases used within the move, the auxiliary verb 'be' is used to define institutional types and provide description of the location and characteristics of the region where the institution is located, and the verb phrases such as 'offer', 'serve', 'provide', 'support' and 'allow' are frequently used to describe programs and facilities of the institutions.

As the steps within the move describe what the institution is, where it is located and what it has done and is doing, significant parts of the move reflect the identity of the institutions. For example, in the 'identity' step, three colleges claim their identity by stating: "[college name] is a comprehensive college", "[college name] has deliberately chosen to be a community college" and "[college name]'s mission, as a comprehensive community college." In the 'location' step, the institutions express their uniqueness and the uniqueness of the region they are located in: the university is "situated in the vibrant city of [name of the city] on [name] territory and the traditional homeland of the Métis" in a "dynamic, forward-looking province"; the university is "dynamic, metropolitan and multi-cultural"; the college is "serving greater [city name] region." In addition, the 'programs offer' and 'facilities' steps state what the institutions do: provide

\footnotetext{
${ }^{2}$ Métis peoples are recognized as one of Canada's aboriginal peoples under the Constitution Act of 1982. 
"flexible learning arrangements"; "experiential education opportunities"; "relevant real-word training"; list their facilities such as "gourmet restaurants", "auto shop", "salon and spa". As can be seen, adjectives with positive connotations such as 'vibrant', 'beautiful', 'dynamic', forwardlooking', 'metropolitan', 'flexible', 'relevant' and 'real-world' are used to highlight the attractive qualities of the institutions and regions.

Another notable feature within this move unique to college mission statements is that it includes figures and details in the description of the college campus size, student numbers and demographics, degrees and programs offered, numbers of employees, annual budgets, engagement with the job market, and so on. It may be reasonable to say that an additional communicative purpose of college mission statements as compared to university mission statements is to provide information about their services and facilities because they are usually less known to the public and because they intend to attract more vocational job oriented students.

\section{'Justification of reputation' move}

As this move was only presented in only one mission statement, it was impossible to identify its lexico-grammatical patterns. The move is written in declarative sentences in the present tense, using expressions such as 'have a well-deserved reputation for', 'innovative, energetic faculty, staff, student, and alumni community', 'research infrastructure unique in Canada', 'deliver widest programs', 'displays remarkable resilience and a commitments', 'university's unique spirit' and so on. As can be seen, adjectives with a positive connotation such as 'well-deserved', innovative', 'energetic', 'unique', 'remarkable' are used to emphasize the positive image of the institution and to justify its reputation. However, in this move, no figures or details are provided unlike in the 'current status of development' move.

\section{'Overview' move}

An analysis of the 'overview' move did not show notable lexico-grammatical patterns due to the limited numbers of samples as this move was presented in two college mission statements. 
This move did not seem to reflect organizational identity at the first look, but it included some identity features. For instance, the College of New Caledonia was the only institution that expressed the existence of its 'strategic plan' in its mission statement, stating its mission is a 'part of its five-year 'strategic plan development process.' Another finding to note is that the George Brown College mission statement specifies the sentence subject (participant) of the mission to its staff, faculty and administration, stating 'the staff, faculty and administration are united by a set of shared values and objectives....to meet the needs of students and employers', which seemingly implies that the institution considers its staff, faculty and administration as service providers and its students and employers as clients. This subject choice is different from a typical sentence subject choice identified in other mission statements are the names of the institution, pronoun 'we', 'our school/institutions', or the whole university community.

\section{Word frequency}

The word frequency analysis has clarified and confirmed the results of the qualitative lexico-grammatical analysis. While the keyword lists of university and college corpora (Appendix E) share a number of common words such as 'mission', 'value', 'vision', 'learning', 'community', 'students' and so on, some differences are apparent. In the university mission statement corpus, 15 most frequently used words are academic-related such as 'research', 'knowledge', 'teaching', 'academic' and 'excellence'. At the same time, the college mission statement corpus includes keywords such as 'success', 'employees' and 'work.' This finding indicates that both types of institutions share the same communicative purpose of presenting their mission, vision, and values to the readers, but there is a difference in their commitments and principles, stemming from different institutional purposes and functions that the two types of institutions represent.

The detailed genre analysis combined with the lexico-grammatical analysis of a small corpus of the Canadian universities and colleges mission statements indicates that the organizational identity is projected throughout the whole text of the mission statement with a particular emphasis provided in the 'commitments' and 'values/principles' moves. Some differences have been found in how the organizational identity is constructed in Canadian university and college mission statements, which can be explained by the different nature of 
these post-secondary institutions and the prospective students they target.

The analysis presented in the study provides a blueprint for pedagogical interventions that may inform the choices future students make when looking for appropriate post-secondary institutions both within their countries and abroad.

\section{Conclusion}

The study has investigated the discursive construction of the organizational identity in a small corpus of 14 mission statements collected from the public websites of two types of Canadian post-secondary institutions, colleges and universities, by analyzing their rhetorical move-step structure and lexico-grammatical features. The results of the move-step genre analysis indicate that all the mission statements include 'commitments' as an obligatory move and that the majority of them include the 'values/principles' move. Such similarities in the content and move structure demonstrate that the main communicative purpose of the Canadian post-secondary institution mission statement genre is to communicate the institution's commitments and values/principles to the readers, including prospective students. On the basis of the analysis, is reasonable to conclude that the college and university mission statements belong to the same genre, as both texts share the common communicative purpose and content as well as lexical and grammatical features, which realize the specific rhetorical function of each move. However, a detailed analysis of the steps within each individual move across the mission statements shows that the primary commitments and values/principles of the university mission statements are different from those of college mission statements. This finding reflects the differences in institutional purpose and function of the two types of Canadian post-secondary institutions and helps to identify the core identity of each institution.

Another finding of the study is that while organizational identity is most clearly represented in the 'commitments' and 'values/principles' moves, it is communicated throughout the whole text. While it seems that some of the mission statement samples are more focused on creating and projecting a strong organizational identity, it is essential to investigate the context in which each text is written and used in order to discover and identify further or ancillary purposes of the texts (ASKEHAVE; SWALES, 2001). Based on the findings mentioned above, this 
study has practical implications for the development of mission statements for post-secondary institutions. While this study identified a generic move-step structure and recurring lexicogrammatical features employed in mission statements of Canadian colleges and universities, practitioners creating or revising school mission statements can be made aware of the recurrent elements in academic mission statements and apply the best strategies that fit their institutional type and convey their institutional flavor.

A pedagogical implication of the study concerns the issues of academic literacy. Prospective students attempting to navigate complex systems of post-secondary institutions are faced with multiple texts that appear on institutional website, one of the most prominent of which is the institutional mission statement. Raising future students' awareness of the communicative purposes of such statements and the rhetorical and linguistic strategies used by the institutions to construct their identities may assist students with making informed choices of the institutions they wish to apply to and join in the future. Such supports can be equally helpful to both native speakers of the languages such institutions use and international students.

\section{References}

ALBERT, S.; WHETTEN, D. A. Organizational identity. In: CUMMINGS, L. L.; STAW, B.M. Research in organizational behavior. Greenwich, CT: JAI Press, 1985,p. 263-295.

ALLISON, J. Advancing strategic communication through mission statements: Creation of a natural language taxonomy. Academy of Strategic Management Journal, v. 16, n. 3, p. 1-15, 2017.

ANTHONY, L. [Computer Software (2019)]. AntConc (Version 3.5.8) Tokyo, Japan: Waseda University. Available at: <https://www.laurenceanthony.net/software>

ASKEHAVE, I.; SWALES, J. M. Genre identification and communicative purpose: A problem and a possible solution. Applied Linguistics, v.22, n. 2, Oxford University Press. p.195-212, 2001.

ATAI, M. R.; ASADNIA, F. The prestigious world university on its homepage: A move analysis of an introductory genre set. Iranian Journal of Applied Linguistics, v. 19, n. 1, p.1-34, 2017.

BART, C. K.; BAETZ, M. C. The relationship between mission statements and firm performance: An exploratory study. Journal of Management Studies, v. 35, n. 6, p.823-853, 1998. 
BAWARSHI, A. S.; REIFF, M. J. Genre: An introduction to history, theory, research, and pedagogy (Reference Guides to Rhetoric and Composition). Colorado and Indiana: Parlor Press and the WAC Clearinghouse, 2010.

DAVID, M. E.; DAVID, F. R.; DAVID, F. R. Mission statement theory and practice: A content analysis and new direction. International Journal of Business, Marketing, and Decision Sciences, v.7, n. 1, p.95-110, 2014.

FALSEY, T. A. Corporate philosophies and mission statements: A survey and guide for corporate communicators and management. Westport, CT: Greenwood, 1989.

GIOIA, D. A.; PATVARDHAN, S. D.; HAMILTON, A.L.; CORLEY, K.G. Organizational identity formation and change. The Academy of Management Annals, v.7, n. 1, p.123-192, 2013.

GIOIA, D. A.; PRICE, K.N.; HAMILTON, A.L.; THOMAS, J.B. Forging an identity: An insider-outsider study of processes involved in the formation of organizational identity. Administrative Science Quarterly, v. 55, n. 1, p. 1-46, 2010

HENRY, A.; ROSEBERRY, R. L. An evaluation of a genre based approach to the teaching of EAP/ESP writing. Tesol Quarterly, v. 32, n. 1, p. 147-156, 1998.

HLADCHENKO, M. The organizational identity of Ukrainian universities as claimed through their mission statements. Tertiary Education and Management, v.22, n. 4, p.376-389, 2016. HYON, S. Introducing genre and English for specific purposes, New York, NY: Routledge, 2018.

KNIGHT, J. Internationalization at Canadian universities: The changing landscape. Ottawa: Association of Universities and College of Canada, 1995.

LABIANCA, G.; FAIRBANK, J. F.; THOMAS, J. B.; GIOIA, D. A.; UMPHRESS, E. E. Emulation in academia: Balancing structure and identity. Organization Science, v.12, n. 3, p.312-330, 2001.

LEUTHESSER, L.; KOHLI, C. Corporate identity: The role of mission statements. Business Horizons, v. May-June, p.59-66, 1997.

MONTESINOS, P.; CAROT, J. M.; MARTINEZ, J.M.; MORA, F. Third mission ranking for world class universities: Beyond teaching and research. Higher Education in Europe, v.33, n. 2/3, p.259-271, 2008.

MORPHEW, C. C.; HARTLEY, M. Mission statements: A thematic analysis of rhetoric across institutional type. The Journal of Higher Education, v.77, n. 3, p.456-471, 2006.

MORRISH, L.; SAUNTSON, H. Business-facing motors for economic development: An appraisal analysis of visions and values in the marketized UK university. Critical Discourse Studies, v.10, n. 1, p.61-80, 2013. 
PEARCE II, J. A.; DAVID, F. R. Corporate mission statements: The bottom line. Academy of Management Executive, v.1, n. 2, p.109-116, 1987.

SUN, Y.; JIANG, J. Metaphor use in Chinese and US corporate mission statements: A cognitive sociolinguistic analysis. English for Specific Purposes, v.33, n. special Issue, p.4-14, 2013.

SWALES, J. M. Genre analysis: English in academic and research settings. New York: Cambridge University Press, 1990.

SWALES, J.; ROGERS, P. "Discourse and the Projection of Corporate Culture: The Mission Statement." Discourse \& Society 2(6): 223-242, 1995. <http://hdl.handle.net/2027.42/67339>

WILLIAMS, L. S. The mission statement: A Corporate reporting tool with a past, present, and future. Journal of Business Communication, v.45, n. 2, p. 94-119, 2008. 
Appendix A. College and University Mission Statement Samples

1. University of Saskatchewan

2. University of Waterloo

3. York University

4. McGill University

5. University of Calgary

6. University of Manitoba

7. University of Alberta

8. Okanagan College

9. Confederation College

10. Fanshawe College

11. Vancouver Community College

12. Loyalist College

13. College of New Caledonia

14. George Brown College 
Appendix B. Summary of Move-step Analysis- University Mission Statement Samples

\begin{tabular}{|c|c|c|c|c|c|c|c|}
\hline $\begin{array}{c}\text { Name of } \\
\text { Institution }\end{array}$ & $\begin{array}{l}\text { University of } \\
\text { Saskatchewan }\end{array}$ & $\begin{array}{l}\text { University of } \\
\text { Waterloo }\end{array}$ & York University & McGill University & $\begin{array}{l}\text { University of } \\
\text { Calgary }\end{array}$ & $\begin{array}{l}\text { University of } \\
\text { Manitoba }\end{array}$ & $\begin{array}{l}\text { University of } \\
\text { Alberta }\end{array}$ \\
\hline \multirow[t]{5}{*}{$\begin{array}{l}\text { Moves/ } \\
\text { Steps }\end{array}$} & $\begin{array}{l}\text { Current status of } \\
\text { development } \\
\text {-Location } \\
\text {-Characteristics } \\
\text { of the region }\end{array}$ & \multirow{5}{*}{$\begin{array}{l}\text { Commitments } \\
\text {-Practical } \\
\text { orientation } \\
\text {-Student service } \\
\text { and support } \\
\text {-Approaches to } \\
\text { fulfill } \\
\text { commitments } \\
\text {-International } \\
\text { perspective } \\
\text {-Partnership }\end{array}$} & $\begin{array}{l}\text { Commitments } \\
\text {-Knowledge } \\
\text {-Academic } \\
\text { excellence }\end{array}$ & \multirow[t]{3}{*}{$\begin{array}{l}\text { Commitments } \\
\text {-Knowledge } \\
\text {-Academic } \\
\text { excellence } \\
\text {-International } \\
\text { perspective } \\
\text {-Contribution to } \\
\text { society }\end{array}$} & \multirow[t]{3}{*}{$\begin{array}{l}\text { Commitments } \\
\text {-Partnership } \\
\text {-Academic } \\
\text { excellence } \\
\text {-Community } \\
\text { perspective } \\
\text {-Student support }\end{array}$} & \multirow{3}{*}{$\begin{array}{ll}\text { Commitments } \\
\text { - } & \text { Knowledge } \\
\text { - } & \text { Contributio } \\
& n \text { to the } \\
& \text { society } \\
\text { - } & \text { Internation } \\
& \text { al } \\
& \text { perspective } \\
- & \text { Academic } \\
& \text { excellence } \\
- & \text { Innovation } \\
- & \text { Community } \\
& \text { perspective }\end{array}$} & \multirow{3}{*}{$\begin{array}{l}\text { Commitments } \\
\text {-Inspiration } \\
\text {-Contribution to } \\
\text { society } \\
\text {-Community } \\
\text { perspective } \\
\text {-Knowledge } \\
\text {-Academic } \\
\text { excellence } \\
\text {-Partnership } \\
\text {-International } \\
\text { perspectives }\end{array}$} \\
\hline & \multirow{3}{*}{$\begin{array}{l}\text { Justification of } \\
\text { reputation } \\
\text {-Faculty, staff } \\
\text { and alumni } \\
\text { community } \\
\text {-Research } \\
\text { infrastructure } \\
\text {-Programs offer } \\
\text {-Other positive } \\
\text { characteristics }\end{array}$} & & $\begin{array}{l}\text { Current status of } \\
\text { development } \\
\text { - Location } \\
\text {-Characteristics } \\
\text { of the region } \\
\text {-Identity }\end{array}$ & & & & \\
\hline & & & $\begin{array}{l}\text { Commitments } \\
\text { International } \\
\text { perspective }\end{array}$ & & & & \\
\hline & & & & \multirow{2}{*}{$\begin{array}{l}\text { Values/ } \\
\text { principles } \\
\text {-Academic } \\
\text { principles }\end{array}$} & \multirow{2}{*}{$\begin{array}{l}\text { Values/ } \\
\text { principles } \\
\text {-Overview } \\
\text {-Committed } \\
\text { values }\end{array}$} & \multirow{2}{*}{$\begin{array}{l}\text { Values/ } \\
\text { principles } \\
\text {-Overview } \\
\text {-Committed } \\
\text { values }\end{array}$} & \multirow{2}{*}{$\begin{array}{l}\text { Values/ } \\
\text { principles } \\
\text {-Overview } \\
\text {-Committed } \\
\text { values }\end{array}$} \\
\hline & $\begin{array}{l}\text { Commitments } \\
\text {-Sustainability } \\
\text {-Academic } \\
\text { excellence } \\
\text {-International } \\
\text { perspectives } \\
\text {-Contribution to } \\
\text { society } \\
\text {-Community } \\
\text { perspective }\end{array}$ & & $\begin{array}{l}\text { Values/ } \\
\text { principles } \\
\text {-Committed } \\
\text { values } \\
\text {-Slogan }\end{array}$ & & & & \\
\hline
\end{tabular}




\section{Appendix B. Summary of Move-step Analysis - College Mission Statement Samples}

\begin{tabular}{|c|c|c|c|c|c|c|c|}
\hline $\begin{array}{c}\text { Name of } \\
\text { Institution }\end{array}$ & $\begin{array}{l}\text { Okanegan } \\
\text { College }\end{array}$ & $\begin{array}{c}\text { Confederation } \\
\text { College }\end{array}$ & $\begin{array}{l}\text { Fanshawe } \\
\text { College }\end{array}$ & $\begin{array}{l}\text { Vancouver } \\
\text { community } \\
\text { College }\end{array}$ & $\begin{array}{l}\text { Loyalist } \\
\text { College }\end{array}$ & $\begin{array}{c}\text { College of } \\
\text { New } \\
\text { Caledonia }\end{array}$ & $\begin{array}{l}\text { George } \\
\text { Brown } \\
\text { College }\end{array}$ \\
\hline \multirow[t]{9}{*}{$\begin{array}{l}\text { Moves/ } \\
\text { Steps }\end{array}$} & \multirow{6}{*}{$\begin{array}{l}\text { Commitments } \\
\text { Student success } \\
\text {-Lifelong } \\
\text { learning } \\
\text { - } \\
\text { Competitiveness } \\
\text {-Quality learning } \\
\text { experience } \\
\text {-Freedom of } \\
\text { expression and } \\
\text { thinking } \\
\text {-International } \\
\text { perspective } \\
\text {-Community } \\
\text { perspective } \\
\text {-Partnership } \\
\text {-Practical } \\
\text { orientation of } \\
\text { education }\end{array}$} & \multirow[t]{6}{*}{$\begin{array}{l}\text { Commitments } \\
\text {-Student } \\
\text { success }\end{array}$} & \multirow{4}{*}{$\begin{array}{l}\text { Current status } \\
\text { of } \\
\text { development } \\
\text { - Identity } \\
\text { - Brief } \\
\text { location } \\
\text {-Campus size } \\
\text { \& location } \\
\text { - Demograph } \\
\text { y } \\
\text { - Programs } \\
\text { offer }\end{array}$} & \multirow{2}{*}{$\begin{array}{l}\text { Current status } \\
\text { of } \\
\text { development } \\
\text {-Campus } \\
\text { location } \\
\text {-Programs } \\
\text { offer } \\
\text {-Facilities }\end{array}$} & \multirow{3}{*}{$\begin{array}{l}\text { Commitments } \\
- \\
\text { Empowerme } \\
\text { nt } \\
\text {-Practical } \\
\text { orientation of } \\
\text { education } \\
\text {-Community } \\
\text { perspective }\end{array}$} & $\begin{array}{l}\text { Overview } \\
\text {-overview of } \\
\text { institutional } \\
\text { strategic plan }\end{array}$ & \multirow[t]{2}{*}{$\begin{array}{l}\text { Overview } \\
\text {-overview of } \\
\text { vision, } \\
\text { mission and } \\
\text { values }\end{array}$} \\
\hline & & & & & & \multirow{6}{*}{$\begin{array}{l}\text { Commitments } \\
\text { - Community } \\
\text { perspective } \\
\text { - Lifelong } \\
\text { learning } \\
\text { - Student } \\
\text { support } \\
\text { - Practical } \\
\text { orientation } \\
\text { of } \\
\text { education } \\
\text { - Quality } \\
\text { learning } \\
\text { experience } \\
\text { - Student } \\
\text { success } \\
\text { - Competitiv } \\
\text { eness } \\
\text {-International } \\
\text { perspectives }\end{array}$} & \\
\hline & & & & \multirow{3}{*}{$\begin{array}{l}\text { Commitments } \\
\text { - } \\
\text { Competitiven } \\
\text { ess } \\
\text {-Student } \\
\text { support } \\
\text {-Student } \\
\text { success } \\
\text { - Practical } \\
\text { orientation of } \\
\text { education }\end{array}$} & & & \multirow{5}{*}{$\begin{array}{l}\text { Commitments } \\
\text {-Quality } \\
\text { learning } \\
\text { experience } \\
\text { - } \\
\text { Competitiven } \\
\text { ess } \\
\text { - Practical } \\
\text { orientation of } \\
\text { education } \\
\text {-Life-long } \\
\text { learning }\end{array}$} \\
\hline & & & & & $\begin{array}{l}\text { Values/ } \\
\text { principles } \\
\text {-Overview } \\
\text {-Committed } \\
\text { values }\end{array}$ & & \\
\hline & & & \multirow{4}{*}{$\begin{array}{l}\text { Commitments } \\
\text { - Student } \\
\text { success } \\
\text { - Quality } \\
\text { learning } \\
\text { experience } \\
\text { - Internationa } \\
\text { I perspective } \\
\text { - Practical } \\
\text { orientation } \\
\text { of education }\end{array}$} & & $\begin{array}{l}\text { Current status } \\
\text { of } \\
\text { development } \\
\text {-Historical }\end{array}$ & & \\
\hline & & & & $\begin{array}{l}\text { Current } \\
\text { status of } \\
\text { development } \\
\text {-Demography } \\
\text {-Financial }\end{array}$ & $\begin{array}{l}\text {-Role } \\
\text {-Influence in } \\
\text { the } \\
\text { community } \\
\text {-Campus size }\end{array}$ & & \\
\hline & \multirow{3}{*}{$\begin{array}{l}\text { Values/ } \\
\text { principles } \\
\text {-Committed } \\
\text { values }\end{array}$} & \multirow{3}{*}{$\begin{array}{l}\text { Values/ } \\
\text { principles } \\
\text {-Committed } \\
\text { values }\end{array}$} & & situation & \multirow{3}{*}{$\begin{array}{l}\text { Demography } \\
\text {-Identity }\end{array}$} & & \\
\hline & & & & $\begin{array}{l}\text {-Role } \\
\text {-Partnership }\end{array}$ & & \multirow{2}{*}{$\begin{array}{l}\text { Values/ } \\
\text { principles } \\
\text {-Overview } \\
\text {-Committed } \\
\text { values }\end{array}$} & \multirow{2}{*}{$\begin{array}{l}\text { Values/ } \\
\text { principles } \\
\text {-Committed } \\
\text { values }\end{array}$} \\
\hline & & & $\begin{array}{l}\text { Values/ } \\
\text { principles } \\
\text {-Committed } \\
\text { values }\end{array}$ & $\begin{array}{l}\text { Values/ } \\
\text { principles } \\
\text {-Committed } \\
\text { values } \\
\text {-Expression of } \\
\text { institutional } \\
\text { commitments }\end{array}$ & & & \\
\hline
\end{tabular}


Appendix C. Move-step Analysis- University Mission Statement Sample

\begin{tabular}{|c|c|c|}
\hline $\begin{array}{c}\text { Name of } \\
\text { school }\end{array}$ & Moves & Corpus \\
\hline $\begin{array}{l}\text { University } \\
\text { of } \\
\text { Waterloo }\end{array}$ & $\begin{array}{l}\text { Commitments } \\
\text {-Practical } \\
\text { orientation of } \\
\text { education } \\
\text {-Student support } \\
\text {-Approaches to } \\
\text { fulfill commitments } \\
\text {-International } \\
\text { perspective } \\
\text {-Partnership }\end{array}$ & $\begin{array}{l}\text { Mission } \\
\text { Inspire Waterloo students to connect to the possibilities in a continuously } \\
\text { changing world of work. Enable them to bridge their academic and } \\
\text { workplace knowledge. Challenge them to learn, grow and contribute } \\
\text { wherever they go. } \\
\text { To accomplish our mission, in partnership with students, employers, } \\
\text { faculty and staff, we: } \\
\text { - facilitate, through a competitive employment process, } \\
\text { access to meaningful work opportunities related to } \\
\text { students' academic studies and their aspirations. } \\
\text { open doors to diverse employment opportunities in Canada } \\
\text { and internationally and draw employers to Waterloo's rich } \\
\text { talent pool. } \\
\text { support students in acquiring, reinforcing and enhancing the } \\
\text { capabilities essential in a knowledge-driven economy and } \\
\text { borderless workplace. } \\
\text { Vision } \\
\text { Demonstrate innovative, global leadership in co-operative education and } \\
\text { career development, and position Waterloo as a top choice for students } \\
\text { and employers. } \\
\text { We move closer to our vision when we: } \\
\text { collaborate with our partners to shape and promote } \\
\text { - UWaterloo's thought leadership and best practices. } \\
\text { the University's goals in Canada and internationally. } \\
\text { foster a dynamic learning environment in CECA that sparks } \\
\text { and celebrates new ideas and provides opportunities for all } \\
\text { who work here to make a positive impact. }\end{array}$ \\
\hline
\end{tabular}


Appendix C. Move-step Analysis - College Mission Statement Sample

\begin{tabular}{|c|c|c|}
\hline $\begin{array}{c}\text { Name of } \\
\text { school }\end{array}$ & Moves & Corpus \\
\hline \multirow[t]{3}{*}{$\begin{array}{l}\text { College of } \\
\text { New } \\
\text { Caledonia }\end{array}$} & $\begin{array}{l}\text { Overview } \\
\text {-Overview } \\
\text { institutional } \\
\text { strategic plan }\end{array}$ & $\begin{array}{l}\text { Our CNC Foundation } \\
\text { During the } 2016 \text { Strategic Plan Development process, the college reviewed } \\
\text { the Mission, the Vision statement and the institutional Values to ensure } \\
\text { they reflect where the CNC is going over the next five years. }\end{array}$ \\
\hline & $\begin{array}{l}\text { Commitments } \\
\text { - Community } \\
\text { perspective } \\
\text { - Lifelong learning } \\
\text { - Student support } \\
\text { - Practical } \\
\text { orientation of } \\
\text { education } \\
\text { - Quality learning } \\
\text { experience } \\
\text { - Student success } \\
\text { - Competitiveness } \\
\text {-International } \\
\text { perspectives }\end{array}$ & $\begin{array}{l}\text { Mission } \\
\text { This is what we are here to do, as the community college in north-central } \\
\text { British Columbia. } \\
\text { The College of New Caledonia's mission, as a comprehensive community } \\
\text { college, is to provide access to lifelong learning and to facilitate the } \\
\text { achievement of educational and personal goals. We are responsive to the } \\
\text { diverse needs of our students, our employees, and the communities in our } \\
\text { region. In a dynamic, consultative environment, we deliver quality } \\
\text { programs and promote the success of every student. } \\
\text { Vision } \\
\text { This is what we intend to become within a certain timeframe. } \\
\text { The College of New Caledonia's will be recognized regionally and } \\
\text { internationally for implementing effective learning opportunities, which } \\
\text { will increase educational access for our learners. Students, employees and } \\
\text { communities will share "one experience" of CNC. Our programs will support } \\
\text { the development of local, regional and global leaders. }\end{array}$ \\
\hline & $\begin{array}{l}\text { Values/principles } \\
\text {-Overview } \\
\text {-Committed values }\end{array}$ & $\begin{array}{l}\text { Values } \\
\text { At CNC, our values guide the work that we do and the decisions that are } \\
\text { made.|I } \\
\text { Respect: We respect and value each individual by being inclusive and } \\
\text { embracing the diversity of our learners and college communities. } \\
\text { Accountability: We are accountable to each other and to the college } \\
\text { community for our actions and for achieving our commitments. } \\
\text { Integrity: We act with integrity, fulfilling promises and ensuring open, } \\
\text { respectful relationships. } \\
\text { Transparency: We conduct ourselves in an open, honest, and transparent } \\
\text { manner. } \\
\text { Relationships: We work together to advance CNC in its academic mission } \\
\text { and in fostering respectful relationships. }\end{array}$ \\
\hline
\end{tabular}




\section{WSE HORIZONTES}

Appendix D. Word frequency analysis- 25 most frequent content words in mission statements

\begin{tabular}{|l|l|l|l|l|}
\hline Type & \multicolumn{2}{|c|}{ University } & \multicolumn{2}{c|}{ College } \\
\hline Rank & Word & Frequency & Word & Frequency \\
\hline 1 & university & 24 & college & 30 \\
\hline 2 & mission & 14 & student(s) & 30 \\
\hline 3 & learning & 13 & community & 19 \\
\hline 4 & research & 13 & mission & 15 \\
\hline 5 & knowledge & 12 & values & 14 \\
\hline 6 & vision & 12 & learners & 13 \\
\hline 7 & Canada & 9 & learning & 12 \\
\hline 8 & community & 9 & vision & 11 \\
\hline 9 & values & 9 & communities & 10 \\
\hline 10 & teaching & 8 & success & 10 \\
\hline 11 & value & 8 & employees & 8 \\
\hline 12 & world & 8 & respect & 8 \\
\hline 13 & academic & 7 & work & 8 \\
\hline 14 & students & 7 & diversity & 7 \\
\hline 15 & excellence & 5 & programs & 7 \\
\hline 16 & freedom & 5 & faculty & 6 \\
\hline 17 & dynamic & 4 & graduates & 6 \\
\hline 18 & education & 4 & industry & 6 \\
\hline 19 & faculty & 4 & region & 6 \\
\hline .20 & global & 4 & services & 6 \\
\hline 20 & innovation & 4 & staff & 6 \\
\hline 21 & innovative & 4 & access & 5 \\
\hline 22 & outstanding & 4 & employers & 5 \\
\hline 23 & society & 4 & excellence & 5 \\
\hline 24 & staff & 4 & needs & 5 \\
\hline 25 & support & 4 & partners & 5 \\
\cline { 2 - 5 } & work & 4 & & \\
\hline
\end{tabular}

Recebido em outubro de 2019.

Aprovado em dezembro de 2019. 